\title{
Anti-Zika virus activity and chemical characterization by ultra-high performance liquid chromatography (UPLC-DAD-UV-MS) of ethanol extracts in Tecoma species
}

Adriana Cotta Cardoso Reis ${ }^{1}$, Breno Mello Silva², Hélia Maria Marques de Moura', Guilherme Rocha Pereira ${ }^{3}$ and Geraldo Célio Brandão ${ }^{1 *}$ (D)

\begin{abstract}
Background: Plant species from the genus Tecoma are found in tropical and subtropical regions around the world. Some of them are grown as ornamental plants and others can be used as medicinal plants. In the present study, ethanolic extracts from trunks and leaves of Tecoma species were tested in vitro using assays against the Zika virus.

Methods: There was a total of 8 extracts obtained from different anatomical parts of three Tecoma species. The Tecoma castaneifolia, T. garrocha, T. stans var. angustata and T. stans var. stans were prepared by percolation with ethanol. The antiviral activity was assayed in vitro against the Zika virus by the MTT colorimetric method $(n=3)$. The UPLC-DAD-MS analysis of ethanolic extracts was performed from all the studied species. The biofractionation of $T$. stans var. stans trunk extract using different separation techniques led to the isolation of crenatoside compound.

Results: Ethanolic extract from Tecoma species leaves were more active against the Zika virus (EC 50149.90 to $61.25 \mu \mathrm{g} / \mathrm{mL}$ ) when compared to the trunk extracts tested (EC 50131.0 to $66.79 \mu \mathrm{g} / \mathrm{mL}$ and two were not active). The ethyl acetate and aqueous fractions obtained from T. stans var. stans trunk were active against the Zika virus with $\mathrm{EC}_{50}$ values of 149.90 and $78.98 \mu \mathrm{g} / \mathrm{mL}$, respectively. Crenatoside is a phenylethanoid glycoside isolated from the ethyl acetate of T. stans var. stans trunk extract. This compound was tested and exhibited EC $\mathrm{E}_{50} 34.78 \mu \mathrm{M}$ $(21.64 \mu \mathrm{g} / \mathrm{mL})$, thus demonstrating a better result than the original ethanolic extracts as well as others extracts of Tecoma species, and it was more active than the positive control, ribavirin $(386.84 \mu \mathrm{M})$. Furthermore, its selectivity index was at least 2.5 times higher than the tested ethanolic extracts and 11.1 times more potent than ribavirin.

Conclusion: The Tecoma species demonstrated interesting in vitro activity against the Zika virus. The crenatoside, phenylethanoid glycoside that was for the first time isolated from Tecoma stans var. stans, exhibited a potent and relevant anti-Zika virus activity, being more active than ribavirin (positive control). The data show that crenatoside, was a promising compound with in vitro antiviral activity against the Zika virus.
\end{abstract}

Keywords: Zika virus, Antiviral activity, Tecoma castaneifolia, Tecoma garrocha, Tecoma stans, Phenylethanoid glycoside, Flavonoids, Lignans

\footnotetext{
* Correspondence: celiobrandao@ufop.edu.br; celiobrandao@yahoo.com 'Pharmacy Department, School of Pharmacy, Federal University of Ouro Preto, Campus Morro do Cruzeiro, Ouro Preto, Minas Gerais 35400-000, Brazil Full list of author information is available at the end of the article
}

(c) The Author(s). 2020 Open Access This article is licensed under a Creative Commons Attribution 4.0 International License, which permits use, sharing, adaptation, distribution and reproduction in any medium or format, as long as you give appropriate credit to the original author(s) and the source, provide a link to the Creative Commons licence, and indicate if changes were made. The images or other third party material in this article are included in the article's Creative Commons licence, unless indicated otherwise in a credit line to the material. If material is not included in the article's Creative Commons licence and your intended use is not permitted by statutory regulation or exceeds the permitted use, you will need to obtain permission directly from the copyright holder. To view a copy of this licence, visit http://creativecommons.org/licenses/by/4.0/. The Creative Commons Public Domain Dedication waiver (http://creativecommons.org/publicdomain/zero/1.0/) applies to the data made available in this article, unless otherwise stated in a credit line to the data. 


\section{Background}

The Zika virus (ZIKV) is an infectious mosquito-borne flavivirus. It was first reported in 1947, when monkeys from the Zika Forest in Uganda were infected. Later, the first human casualties were described in Nigeria in 1954. It could be transmitted by different species of Aedes mosquitoes in tropical and subtropical areas. Several cases were described in the Americans, Asia and Africa from 1960s to 1980s. At a later date, there were outbreaks reported in different countries in the pacific. In 2015, Brazil reported the first cases of the Zika virus in Rio Grande do Norte and Bahia [1].

The infection of the Zika virus can be asymptomatic or it may only present the classic symptoms of dengue. Usually, the symptoms start from 3 to 12 days after the mosquito bite. There are ongoing studies of complications caused by the Zika virus during pregnancy. Recently, the Zika virus infection has been linked to cases of microcephaly and pregnancy complications even including fetal loss. Both adults and young people infected can also develop myelitis, neuropathy and Guillain-Barré syndrome, an autoimmune disease in which the immune system attacks the nervous system causing nerve inflammation and muscular weakness [2].

The antivirus therapies play an important role in the research field since viral infections remain a major cause of death around the world. These infections can be controlled, through either preventive prophylactic therapeutic measures (vaccines) or healing drugs. In this context, plants are the source of several bioactive molecules with antiviral activity [3].

Bignoniaceae is a large family of plants that can be found mainly in Central and South America, Africa and Asia. Different metabolites are found, such as terpenoids, naphthoquinones, flavonoids, phenolic compounds among other groups [4]. Some of these compounds presented have antiviral activity [3]. A previous work has shown that Bignoniaceae species are promising sources of antiviral compounds [5-10], including phenylethanoids $[6,8]$, which justifies the studies of the antiviral activity in the species of the genus Tecoma, an important group of plants belonging to this botany family. The data obtained in the present study using chromatographic analyzes combined with hyphenated spectrometric techniques showed that the ethanolic extracts of the species under study were rich in phenylethanoids.

A recent study of extracts from Fridericia formosa were promising since some xanthones were isolated and identified with activity against Herpes virus, Vaccinia virus and the Dengue virus 2 [5]. Previously, Kernan et al., [6] isolated five phenylpropanoid glycosides from the Markhamia lutea species with potent in vitro activity against Respiratory Syncytial virus. There was another relevant discovery during the 1980s, which were antiviral activity reports of lapachol and some of its derivatives, a common naphthoquinone isolated from different Bignoniaceae species [7].

The shrubs and small native trees of the genus Tecoma Juss., with mostly 14 species, are found in tropical regions as described for this family [11]. Some of them produce exuberant flowers, which are used for ornamental purpose in numerous countries, including Brazil [11, 12]. Folk tradition reports the use of these plants as anti-syphilitic, tonic, vermifuge, and diuretic. In Mexico, the extract of Tecoma stans is employed in the control of diabetes. Additional studies of Tecoma plants report isolation and identification of abundant monoterpenic alkaloids. In addition, other secondary metabolites including lapachol, ursolic acid and apigenin were found [13].

The present work shows the anti-Zika virus activity from ethanolic extracts of Tecoma species. Further, phytochemical studies of ethanolic extracts were accomplished using ultra performance liquid chromatography with a coupled mass spectrometer (LCMS). Also, the chromatographic fractionation of $T$. stans trunk extract was performed.

\section{Methods \\ Plant materials}

The following plant species $[T$. casneifolia (BHCB 169768), T. garrocha (BHCB 169765), T. stans var. angustata (BHCB 162001) and T. stans var. stans (BHCB 130095)] were collected in Minas Gerais, Brazil, and a taxonomic determination was made by the botanist Dr. J. R. Stehman, from the Botanical Department at the Institute of Biological Sciences, UFMG, in Belo Horizonte city, Brazil. A voucher of each species was deposited at the BHCB/UFMG herbarium.

\section{Preparation of extracts}

The different parts of the plants (leaves and trunks) were separated and dried in a forced ventilation oven at $40^{\circ} \mathrm{C}$. Then, the plant material was ground in a knife mill and extracted with $96 \%$ ethanol at room temperature. The solvent was removed in a Büchi Rotary Evaporator under the reduced pressure and at the control temperature of $50^{\circ} \mathrm{C}$, leaving dark residues which were kept in a vacuum desiccator until constant weight. The extractive yields of ethanol extracts obtained by cold percolation with ethanol are shown in Table 1.

\section{Apparatus}

Analyses of LC-DAD-MS and LC-ESI-MS/MS were performed using a UPLC Acquity (Waters) ion trap mass spectrometer in the following conditions: positive and negative ion mode; capillary voltage, $3500 \mathrm{~V}$; capillary temperature, $320^{\circ} \mathrm{C}$; source voltage, $5 \mathrm{kV}$; vaporizer temperature, $320^{\circ} \mathrm{C}$; corona needle current, $5 \mathrm{~mA}$; and 
Table 1 Extractive yield of plant material from species of the genus Tecoma

\begin{tabular}{|c|c|c|c|c|}
\hline Specie & & Plant material mass (g) & Extract mass $(g)$ & Yields (\%) \\
\hline \multirow[t]{2}{*}{ Tecoma castaneifolia } & Trunk & 80.0 & 3.0 & 3.8 \\
\hline & Leaves & 349.5 & 30.3 & 8.7 \\
\hline \multirow[t]{2}{*}{ Tecoma garrocha } & Trunk & 55.0 & 6.2 & 11.3 \\
\hline & Leaves & 19.0 & 2.1 & 11.1 \\
\hline \multirow[t]{2}{*}{ Tecoma stans var. angustata } & Trunk & 152.5 & 10.7 & 7.0 \\
\hline & Leaves & 83.0 & 5.9 & 7.1 \\
\hline \multirow[t]{2}{*}{ Tecoma stans var. stans } & Trunk & 463.0 & 54.5 & 11.8 \\
\hline & Leaves & 136.0 & 9.9 & 7.3 \\
\hline
\end{tabular}

sheath gas, nitrogen, $27 \mathrm{psi}$. The analyses were conducted in the full scan mode $(100-2000 \mathrm{Da})$. The ESI$\mathrm{MS}^{2}$ analyses were additionally performed in a UPLC Acquity (Waters) with argon as the collision gas and the collision energy was set at $30 \mathrm{eV}$. Chromatographic separation was done on ACQUITY UPLC HSS column
$(1.7 \mu \mathrm{m}, 50 \times 2 \mathrm{~mm}$ i.d.) (Waters). The mobile phase consisted of water $0.1 \%$ formic acid (solvent A) and acetonitrile $0.1 \%$ formic acid (solvent B). The elution protocol was $0-11 \mathrm{~min}$, linear gradient from 5 to $95 \% \mathrm{~B}$. The flow rate was $0.3 \mathrm{~mL}$ min -1 , and the sample injection volume was $4.0 \mu \mathrm{L}$. The UV spectra was registered

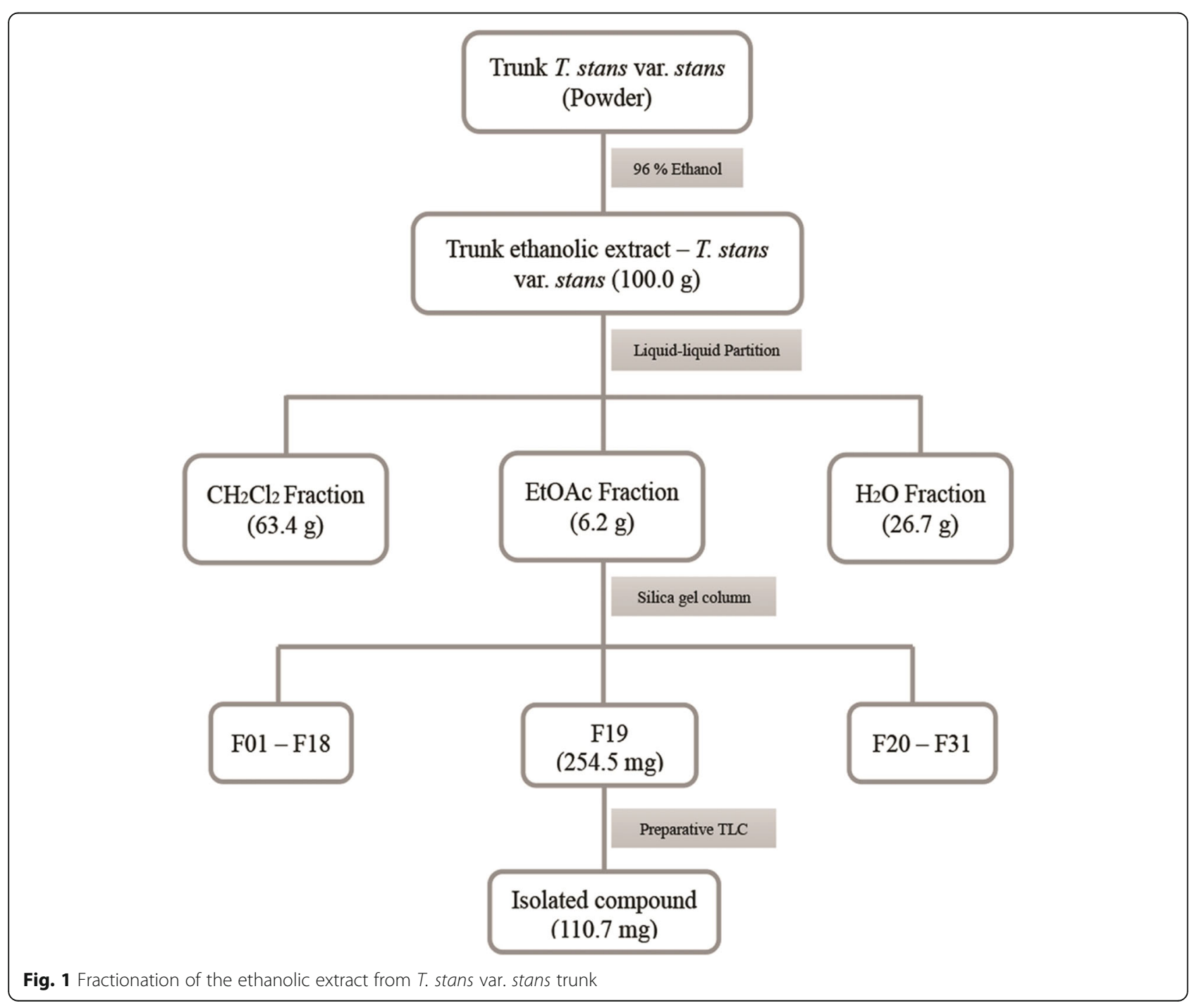


from 190 to $450 \mathrm{~nm}$. The mass spectrometry analysis was performed by Waters ACQUITY ${ }^{\odot}$ TQD equipped with a quadrupole instrument fitted with an electrospray source in the positive and negative ESI mode. The ion spray voltage was: $-4 \mathrm{kV}$; orifice voltage: $-60 \mathrm{~V}$.

Analyzes of the ${ }^{13} \mathrm{C}$ and ${ }^{1} \mathrm{H}$ NMR spectra were used to determine the structure of the isolated compound crenatoside. These analyzes were obtained in the Multi-user Molecule Characterization Laboratory at the Pharmacy School (UFOP) in Ouro Preto, Brazil. A Bruker Ascend ${ }^{\mathrm{m}}$ 400 equipment was used to obtain the spectra. The solvents used were $\mathrm{DMSO}_{d \sigma}$ and MeOD with TMS as internal standard. The chemical shifts are given as $\delta$ (ppm).

\section{Bioguided fractionation of the trunk extract from Tecoma stans var. stans}

A portion of the trunk ethanol extract from $T$. stans var. stans $(50.0 \mathrm{~g}$ ) was dissolved in a methanol-water (6:4) solution. Then, it was fractionated by liquid-liquid partition with dichloromethane $\left(\mathrm{CH}_{2} \mathrm{Cl}_{2}\right)$ and ethyl acetate (EtOAc), sequentially. The corresponding $T$. stans dichloromethane trunk extract ( $13.4 \mathrm{~g})$, T. stans ethyl acetate trunk extract $(19.6 \mathrm{~g})$ and $T$. stans aqueous trunk extract (12.3 g) fractions were obtained (Fig. 1).

These three fractions were tested in vitro against Zika virus and $T$. stans ethyl acetate and the aqueous trunk extract fractions were active. The $T$. stans ethyl acetate was chosen to be fractionated. Hence, a portion of the EtOAc fraction $(8.0 \mathrm{~g})$ obtained from the liquid-liquid partition (from ethanolic extract) was also fractionated on a silica gel column (silica gel 60-230-400 meshMerck $^{\circ}$ ). It was used by increasing the polarity of the solvents in the following order: $\mathrm{CH}_{2} \mathrm{Cl}_{2}, \mathrm{CH}_{2} \mathrm{Cl}_{2} / \mathrm{EtOAc}$ (1:1), EtOAc, $\mathrm{MeOH}$. Finally, 282 fractions were obtained from this purification. Similar fractions were united according to their TLC chromatographic profiles, thus obtaining 31 combined fractions. One of these combined fractions, containing $254.5 \mathrm{mg}$ was rechromatographed on preparative TLC (silica gel $60 \mathrm{~F}_{254}$-Merck $^{\circ}$; $20 \times 20 \mathrm{~cm}$, layer thickness $1.0 \mathrm{~mm})$ using $\mathrm{CH}_{2} \mathrm{Cl}_{2} /$ EtOAc (8:2) as the mobile phase. The result of this new purification was an isolated white compound that yielded $110.7 \mathrm{mg}$ (Fig. 1) and was identified as crenatoside.

\section{Virus and cell line}

The kidney cells of the African green monkey Cercopthecus aeothiops (Vero cell line ATCC ${ }^{\circ}$ CCL- $81^{\text {ma }}$ ) was used in the assays. The cells were cultivated in complete cell medium consisting of Dulbecco's modified Eagle's medium (DMEM, Cultilab, Campinas, SP, Brazil), supplemented with $5 \%$ fetal bovine serum, $50 \mu \mathrm{g} / \mathrm{mL}$ gentamicin, $100 \mathrm{U} / \mathrm{mL}$ penicillin and $5 \mu \mathrm{g} / \mathrm{mL}$ amphotericin $\mathrm{B}$
[8]. The cells were grown in $37^{\circ} \mathrm{C}$ in a humidified atmosphere containing 5\% $\mathrm{CO}_{2}$ and harvested in logphase for experimental use. The Zika virus strain was donated by Dra. E. Kroon (UFMG, Belo Horizonte, Brazil). The virus was titrated by $\mathrm{TCID}_{50}$ in Vero cells, as established by Rodriguez et al., in 1990 [14] and the titers were $1.0 \times 10^{7} \mathrm{TCID}_{50} / \mathrm{mL}$.

\section{Cytotoxicity assay}

The MRC-5 (normal human lung fibroblast cell, ATCC ${ }^{\circ}$ CCL-117 $7^{\mathrm{m}}$ ) and Vero (normal African green monkey kidney cells, ATCC ${ }^{\ominus}$ CCL-81 ${ }^{\mathrm{Tm}}$ ) cell lines were exposed to different concentrations of extracts/fractions/compounds for $48 \mathrm{~h}$ and $72 \mathrm{~h}$, respectively [8]. After incubation, cell viability was assessed by the 3-(4,5-dimethylthiazol-2-yl)2,5-diphenyltetrazolium bromide (MTT, Sigma Aldrich) assay at a concentration of $2 \mathrm{mg} / \mathrm{mL}$ in PBS [14, 15]. Each sample was assayed in three replicates in concentrations ranging from 200 to $0.125 \mu \mathrm{g} / \mathrm{mL}$ for crude ethanol extracts, for the isolated compound the concentrations ranged from 100 to $0.781 \mu \mathrm{g} / \mathrm{mL}$, and for the ribavirin (positive control), the concentrations ranged from 400 to $6.25 \mu \mathrm{g} / \mathrm{mL}$. The cytotoxicity of each sample was expressed as $\mathrm{CC}_{50}$, i.e. and the sample concentration inhibited cell growth by $50 \%$ [8].

\section{Antiviral MTT assays}

The antiviral activity measured by the effective dose of $50 \%\left(E_{50}\right)$ ethanolic extract of Tecoma species, fractions from T. stans and isolated compound was evaluated by the MTT assay [16]. The Vero cell monolayer $\left(2.0 \times 10^{4}\right.$ cells per well $)$ was infected by viral suspensions with titers of $1.0 \times 10^{7} \mathrm{TCID}_{50} / \mathrm{mL},(\mathrm{MOI}=1.0)$, and the Zika virus. Dilutions of the compounds and ethanolic extract in non-cytotoxic concentrations were added to the wells after viral infection. The plates were incubated at $37{ }^{\circ} \mathrm{C}$ in humidified $5 \% \mathrm{CO}_{2}$ atmosphere for a period of $72 \mathrm{~h}$ [8]. The experiments were carried out with eight different concentrations within the noncytotoxic range of the samples. Ribavirin, an antiviral drug known to be active against the Zika virus [17], was used as a positive control to demonstrate that the proposed assay is reliable in determining anti-Zika virus activity, in addition to being a comparison parameter with the samples tested in relation to the evaluation of the antiviral activity. The DMSO is a solvent used to dilute the samples, and it was used to demonstrate that DMSO has no anti-Zika virus activity (negative control). The $50 \%$ inhibitor concentration of the viral effect $\left(E_{50}\right)$ for compounds and ethanolic extract were calculated from concentration-effect-curves after the nonlinear regression analysis [8]. The selective index (SI) is defined as $\mathrm{CC}_{50}$ over $\mathrm{EC}_{50}$ in Vero cell line. The $\mathrm{SI}$ is considered interesting for values higher than two $[18,19]$. 


\section{Statistical analyses}

The statistical calculations of the cytotoxic and antiviral MTT assays were performed with the GraphPad prism 5.0 software package (Statistica). The results are expressed as the mean \pm S.D. of 4 in independent experiments. Student's t-test was used for statistical analyses; $P$ values $>0.05$ were considered to be significant.

\section{In vitro Cytopathic effect inhibition assay}

In order to confirm the anti-ZIKV activity observed in the antiviral MTT assay, the Vero cell monolayer $(9.5 \times$ $10^{6}$ cells per well) was infected by viral suspensions with titers of $1.0 \times 10^{7} \mathrm{TCID}_{50} / \mathrm{mL},(\mathrm{MOI}=1)$, and the Zika virus, during $1 \mathrm{~h}$ for the viral adsorption. Afterwards, the viral suspension was removed and the wells were washed with PBS. Then, the wells were treated with the active concentration of the compound $(25 \mu \mathrm{g} / \mathrm{mL})$ and ethanolic extracts of Tecoma species: T. casneifolia trunk and leaves $(50 \mu \mathrm{g} / \mathrm{mL})$, T. garrocha trunk and leaves $(200 \mu \mathrm{g} /$
$\mathrm{mL}), T$. stans var. angustata leaves $(50 \mu \mathrm{g} / \mathrm{mL})$ and $T$. stans var. stans leaves $(100 \mu \mathrm{g} / \mathrm{mL})$. The plates were incubated at $37^{\circ} \mathrm{C}$ in a humidified $5 \% \mathrm{CO}_{2}$ atmosphere and photographed $24 \mathrm{~h}$ post-infection [20].

\section{Results}

\section{UPLC analysis and identification of compounds from} Tecoma species

The screening, identification, and further confirmation of several components in the studied extracts were performed by UPLC-DAD-MS. This study used a spectrometric method to provide molecular mass ions and characteristic fragment ions. There were eight isolated compounds such as rutin, verbascoside, apigenin, paulownin, paulownin acetate, sesamin, olivil and cycloolivil (Lab Collection), which were used as standards. These standard compounds were used for optimization during separation of phenolic compounds in the UPLC, as well as for the ionization and fragmentation using ESI MS ${ }^{2}$.

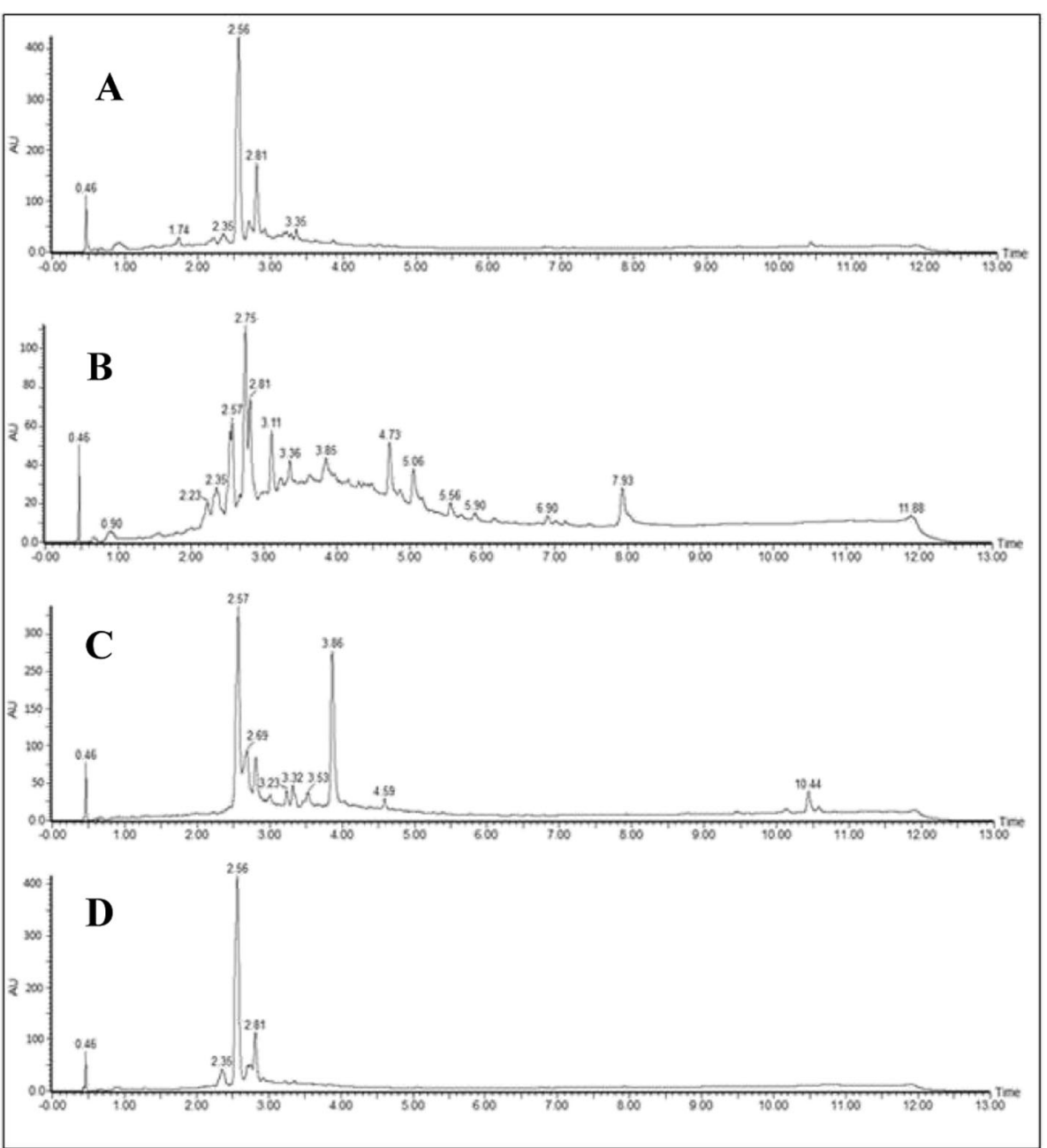

Fig. 2 Chromatographic profile of ethanolic extracts of leaves (a), trunk (b) of T. castaneifolia and leaves (c), trunk (d) of T. garrocha 
The UPLC-DAD fingerprints for the crude ethanolic extracts from Tecoma species are presented in Figs. 2 and 3. The sensitivity was higher when chromatograms were acquired in negative-ion mode mass spectra and it is shown in the Supplementary Material (Fig. 1S to 8S). The positive-ion mode only provided a few peaks. A tentative identification of plant components was performed by detailed fragmentation studies. The obtained spectra were also compared with published data from the literature.

The UPLC-DAD-MS analysis allowed for the identification of phenylethanoids glycoside as one of the main constituents in all the extracts as inferred from their UV spectra which were registered online. Verbascoside and isoverbascoside were the most common detected phenylethanoids. Isoverbascoside is present in all analyzed extracts, exhibiting a retention time of approximately 2.57 min (Figs. 2 and 3, Table 2). The verbascoside was not detected in the leaves extract of $T$. stans var. angustata.

There were some phenylethanoid glycosides found in the ethanolic extracts of the Tecoma species. These molecules were detected and partially characterized by UPLC-MS. The analysis of the extract obtained from the $T$. stans var. stans trunk detected compounds with retention times (Rt) of 2.43 and 3.21 min with molar mass of $638 \mathrm{Da}$. A full-scan mass spectrum in the negative mode detected deprotonated molecules of $\mathrm{m} / \mathrm{z} 637.21$ and 637.22, respectively. Further analysis of the fragment ions by the $\mathrm{MS}^{2}$ experiment suggest the presence of feluric acid residue in two compounds.

The compounds with similar chemical structures were also detected in the extracts of T. stans var. angustata trunks and in the extract of $T$. garrocha leaves (Table 2).

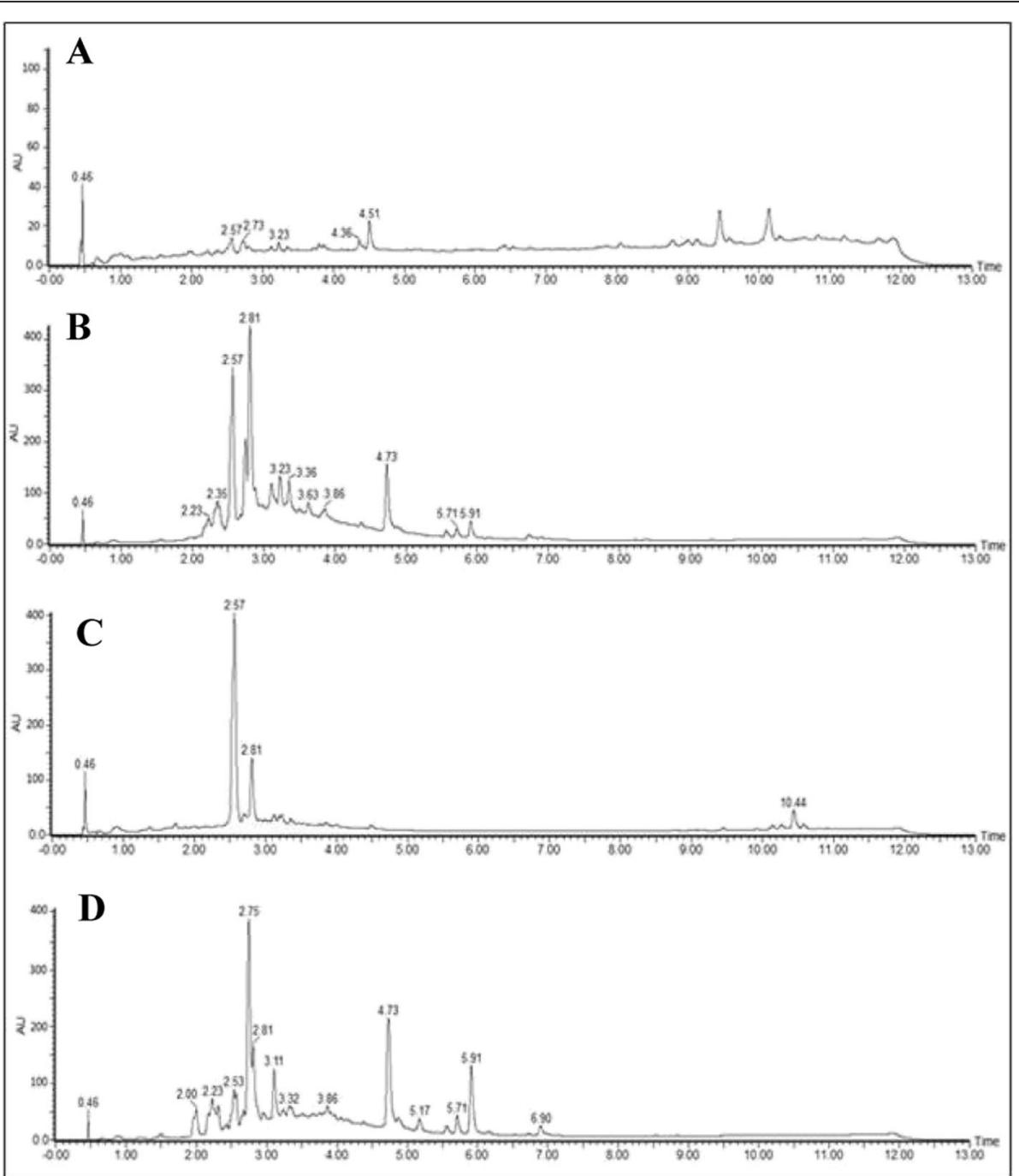

Fig. 3 Chromatographic profile of ethanolic extracts of leaves (a), trunk (b) of T. stans var. angustata and leaves (c), trunk (d) of T. stans var. stans 
Table 2 Phenolic moieties identified in ethanolic extract of leaves and trunk of Tecoma species

\begin{tabular}{|c|c|c|c|c|c|}
\hline Compounds & $\mathrm{RT}(\min )$ & UV (nm) & {$[\mathrm{M}+\mathrm{H}]^{+}(\mathrm{m} / \mathrm{z})$} & {$[\mathrm{M}-\mathrm{H}]^{-}(\mathrm{m} / \mathrm{z})$} & Fragments (m/z) \\
\hline \multicolumn{6}{|l|}{ T. stans var stans (leaves) } \\
\hline Isoverbascoside & 2.57 & 330.6 & 625.75 & 623.66 & $623.45,461.17,315.11,297.21,161.96$ \\
\hline Verbascoside & 2.81 & 329.4 & 625.68 & 623.65 & $623.23,461.21,315.14,297.15,161.89$ \\
\hline \multicolumn{6}{|l|}{ T. stans var stans (trunk) } \\
\hline Phenylpropanoid glycoside & 2.21 & 324.5 & $a_{-}$ & 639.60 & $\begin{array}{l}639.28,621.16,469.35,459.40,323.45 \\
313.19,179.0,161.2,151.25\end{array}$ \\
\hline Olivil & 2.23 & 283.4 & - & 375.51 & 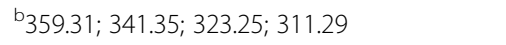 \\
\hline Isoleucosceptoside A & 2.43 & $285.3,324.5$ & - & 637.21 & $637.21,475.07,329.17,179.26,160.94$ \\
\hline Phenylpropanoid glycoside & 2.45 & $284.4,324.4$ & - & 639.35 & $\begin{array}{l}\text { 639.54, 621.35, 487.41, 477.21, 469.35, } \\
459.46,323.2,179.13,161.07\end{array}$ \\
\hline Cycloolivil & 2.53 & $227.5,279.2$ & - & 375.52 & $b_{359.38 ;} 341.35 ; 323.32 ; 311.36$ \\
\hline Isoverbascoside & 2.56 & $286.1,330.4$ & - & 623.67 & $623.43,461.12,315.06,297.28,161.90$ \\
\hline Crenatoside & 2.75 & 330.5 & 623.67 & 621.63 & $621.41,459.37,178.89,160.89$ \\
\hline Verbascoside & 2.81 & $287.5,327.4$ & - & 623.72 & $623.24,461.06,315.12,161.15$ \\
\hline Isocrenatoside & 3.11 & $284.2,327.4$ & - & 621.64 & $621.41,459.12,179.07,160.89$ \\
\hline Leucosceptoside A & 3.21 & $284.4,323.5$ & - & 637.22 & $637.21,501.26,461.23,175.16,161.12$ \\
\hline Paulownin & 4.73 & $232.1,285.3$ & 371.53 & - & b353.43; 325.46; 323.38; 151.15 \\
\hline Paulownin acetate & 5.71 & $237.4,286.1$ & 413.48 & - & $b_{353.23} ; 335.27 ; 325.27 ; 323.25$ \\
\hline Sesamin & 5.91 & $235.1,286.1$ & 355.26 & - & b337.29; 335.40; 319.26; 307.37 \\
\hline \multicolumn{6}{|l|}{ T. stans var angustata (leaves) } \\
\hline Isoverbascoside & 2.57 & 327.4 & - & 623.59 & $623.28,461.17,315.23,297.23,161.77$ \\
\hline Crenatoside & 2.75 & 327.5 & - & 621.57 & $621.34,459.62,178.95,161.01$ \\
\hline Apigenin & 4.36 & $267.4,331.5$ & 271.37 & 269.22 & $268.94,151.12,117.08$ \\
\hline Methoxyluteolin & 4.51 & $267.5,345.5$ & 301.43 & 299.40 & $299.06,284.25,256.03,150.81,147.95$ \\
\hline \multicolumn{6}{|l|}{ T. stans var angustata (trunk) } \\
\hline Olivil & 2.23 & 283.1 & - & 375.52 & 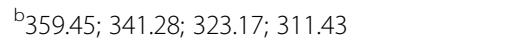 \\
\hline Unidentified & 2.35 & 280.3 & - & 581.65 & $581.25,419.36,401.17,233.10,152.96,118.87$ \\
\hline Isoverbascoside & 2.57 & 330.1 & 625.68 & 623.66 & $623.30,461.37,315.0,297.03,161.90$ \\
\hline Crenatoside & 2.75 & 330.5 & - & 621.63 & $621.34,459.62,178.95,161.01$ \\
\hline Verbascoside & 2.81 & $287.4,327.2$ & 625.75 & 623.66 & $623.24,461.0,315.12,161.03$ \\
\hline Isocrenatoside & 3.11 & $285.3,327.5$ & - & 621.63 & $621.46,459.06,178.82,161.01$ \\
\hline Phenylpropanoid glycoside & 3.23 & $284.1,325.4$ & - & 637.64 & $637.52,490.93,475.20,315.21,175.22,161.19$ \\
\hline Isomartynoside/Martynoside & 3.36 & $286.5,327.2$ & - & 651.58 & $651.13,475.31,328.79,174.92,160.0$ \\
\hline Paulownin & 4.73 & $232.2,285.1$ & 371.55 & - & b353.43; 325.46; 323.38; 151.15 \\
\hline Paulownin acetate & 5.71 & $237.5,286.2$ & 413.47 & - & $b_{353.23 ;} 335.27 ; 325.27 ; 323.25$ \\
\hline Sesamin & 5.91 & $235.4,286.3$ & 355.28 & - & $b_{337.29 ;} 335.40 ; 319.26 ; 307.37$ \\
\hline \multicolumn{6}{|l|}{ T. castaneifolia (leaves) } \\
\hline Unidentified & 2.35 & 281.4 & - & 581.65 & $581.18,419.02,401.4,232.94,152.94,118.91$ \\
\hline Isoverbascoside & 2.56 & $285.1,330.5$ & 625.75 & 623.66 & $623.12,461.12,315.19,297.09,161.0$ \\
\hline Verbascoside & 2.81 & $285.3,327.4$ & 625.68 & 623.59 & $623.37,461.30,315.12,161.0$ \\
\hline \multicolumn{6}{|l|}{ T. castaneifolia (trunk) } \\
\hline Olivil & 2.23 & 283.5 & - & 375.52 & b359.30; 341.39; 323.17; 311.43 \\
\hline Unidentified & 2.35 & 280.3 & - & 581.71 & $581.21,419.12,401.35,232.89,152.97,118.56$ \\
\hline Isoverbascoside & 2.57 & $286.1,330.3$ & - & 623.66 & $623.12,461.12,315.19,297.09,161.0$ \\
\hline
\end{tabular}


Table 2 Phenolic moieties identified in ethanolic extract of leaves and trunk of Tecoma species (Continued)

\begin{tabular}{|c|c|c|c|c|c|}
\hline Compounds & $\mathrm{RT}$ (min) & UV (nm) & {$[\mathrm{M}+\mathrm{H}]^{+}(\mathrm{m} / \mathrm{z})$} & {$[\mathrm{M}-\mathrm{H}]^{-}(\mathrm{m} / \mathrm{z})$} & Fragments (m/z) \\
\hline \multicolumn{6}{|l|}{ T. castaneifolia (trunk) } \\
\hline Crenatoside & 2.75 & 330.5 & - & 621.63 & $621.34,459.62,178.95,161.01$ \\
\hline Verbascoside & 2.81 & $287.2,326.5$ & - & 623.66 & $623.37,461.30,315.12,161.0$ \\
\hline Isocrenatoside & 3.11 & $282.3,326.6$ & - & 621.64 & $621.46,459.06,178.82,161.01$ \\
\hline Isomartynoside/Martynoside & 3.36 & $284.2,323.5$ & - & 651.55 & $651.31,475.51,329.46,175.02,160.91$ \\
\hline Paulownin & 4.73 & $232.3,285.1$ & 371.46 & - & $b_{353.43 ;} 325.46 ; 323.38 ; 151.15$ \\
\hline \multicolumn{6}{|l|}{ T. garrocha (leaves) } \\
\hline Isoverbascoside & 2.57 & 326.5 & 625.68 & 623.66 & $623.37,461.12,315.0,297.47,161.03$ \\
\hline Rutin & 2.69 & $255.2,359.3$ & 611.77 & 609.61 & $609.09,301.11$ \\
\hline Verbascoside & 2.81 & 314.6 & 625.62 & 623.66 & $623.31,461.43,314.78,161.0$ \\
\hline Phenylpropanoid glycoside & 3.23 & 327.1 & 639.60 & 637.83 & $637.46,461.23,443.60,314.83,175.17,160.56$ \\
\hline Methoxyluteolin glycoside & 3.32 & $265.3,331.4$ & 477.48 & 475.55 & b477.50, 315.65, 301.36 \\
\hline \multicolumn{6}{|l|}{ T. garrocha (trunk) } \\
\hline Unidentified & 2.35 & 280.5 & - & 581.65 & $581.13,419.17,401.8,232.97,152.99,118.94$ \\
\hline Isoverbascoside & 2.56 & 330.5 & 625.68 & 623.66 & $623.37,461.12,315.0,297.47,161.03$ \\
\hline Verbascoside & 2.81 & 326.4 & 625.88 & 623.64 & $623.31,461.43,314.78,161.0$ \\
\hline
\end{tabular}

${ }^{a}(-)$ ions undetected

${ }^{b}$ Characteristic $\mathrm{m} / \mathrm{z}$ of ions in positive ion mode

There were two phenylethanoids (Rt 2.75 and $3.11 \mathrm{~min}$ ) showing $622 \mathrm{Da}$, which were detected in the extracts of T. stans var. stans trunk, T. stans var. angustata trunk and leaves, and in the T. castaneifolia trunk (Table 2). The ion fragments, obtained by the $\mathrm{MS}^{2}$ experiment, suggested that these compounds have similar structures to crenatoside (Fig. 4). A full-scan mass spectra in the trunk extracts of T. stans var. angustata and T. castaneifolia negative mode detected deprotonated molecules of $\mathrm{m} / \mathrm{z} 621.63$ and 621.64, respectively. Comparing the data obtained in the $\mathrm{MS}^{2}$ experiments and the literature, it is suggested that compounds with Rt 2.75/3.11 have a similar structure to isocrenatoside/crenatoside.

Lignans were also detected in $T$. stans var. stans, $T$. stans var. angustata and T. castaneifolia trunk extracts. The olivil was present in three extracts. The paulownin, sesamin and paulownin acetate were found in extracts of two varieties of $T$. stans. Lastly, cycloolivil was only detected in the extract of $T$. stans var. stans.

Other phenolic compounds were identified in the leaves extracts of T. stans var. angustata and T. garrocha. Coinjection analyzes with authentic samples allowed for the identification of two flavones: Apigenin as constituent of T. stans var. angustata extract and rutin as constituent of T. garrocha extract. In addition, two different flavones with $300 \mathrm{Da}$ molar mass and $476 \mathrm{Da}$ were detected in the leaves extracts of $T$. stans var. angustata and T. garrocha, partially characterized as methoxyluteolin and methoxyluteolin glycoside, respectively.
Bioguided fractionation and identification of crenatoside isolated from trunk ethanolic extract of $T$. stans var. stans Trunk ethanolic extract of $T$. stans var. stans was fractionated by liquid-liquid partition employing sequential extractions of its aqueous methanol solution with immiscible solvents (dichloromethane and ethyl acetate) led to three fractions: dichloromethane fraction (TSSDF, $13.4 \mathrm{~g}$ ), ethyl acetate fraction (TSSEF, $19.8 \mathrm{~g}$ ) and aqueous fraction (TSSAF, $12.3 \mathrm{~g}$ ). TSSEF and TSSAF fractions were activity against ZIKV with $\mathrm{EC}_{50}$ values of 149.90 and $78.98 \mu \mathrm{g} / \mathrm{mL}$, respectively. The ethyl acetate fraction showed moderate antiviral activity $\left(\mathrm{EC}_{50}\right.$ $149.9 \mu \mathrm{g} / \mathrm{mL}$ ) and preliminary phytochemical investigation by TLC was observed in the presence of phenolic compounds such as lignans and phenylethanoid glycosides (data not shown). Thus, a fraction of ethyl acetate was chosen to be fractionated.

The ethyl acetate fraction $(8.0 \mathrm{~g})$ was further fractionated by silica chromatography allowing isolation of crenatoside $(110.7 \mathrm{mg})$. This phenylethanoid glycoside was identified by ${ }^{13} \mathrm{C}$ and ${ }^{1} \mathrm{H}$ NMR data that are shown in the Supplementary Material (Fig. 9S to 15S). The spectra of the compounds isolated showed in the sensitivity was higher when chromatograms were acquired in negative-ion mode mass spectra in the Supplementary Material (Fig. $1 \mathrm{~S}$ to $8 \mathrm{~S}$ ) and it was confirmed using the ${ }^{1} \mathrm{H}$ and ${ }^{13} \mathrm{C}$ NMR previously reported data for crenatoside [21, 22]. The structure of 


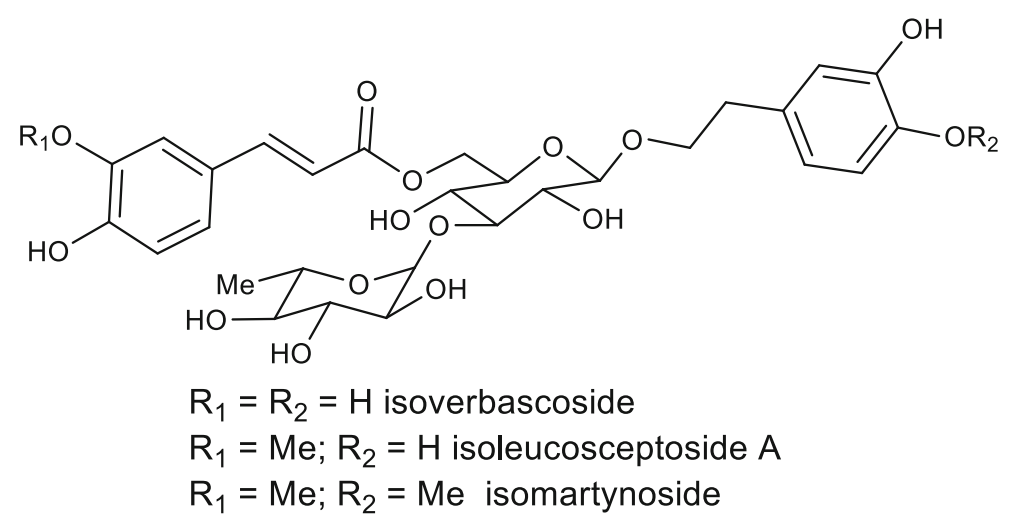

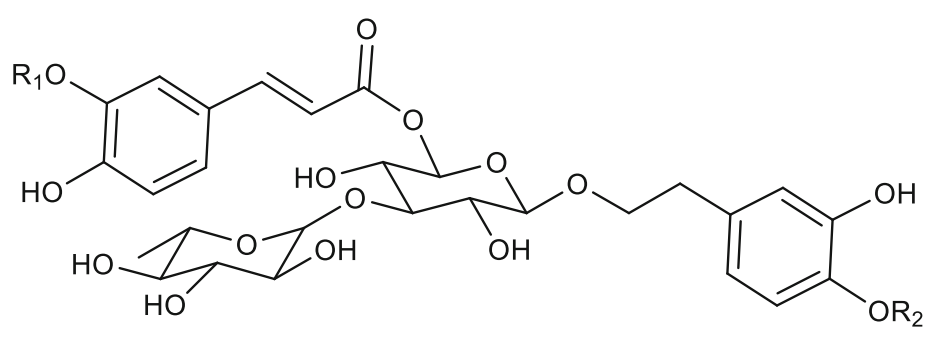

$\mathrm{R}_{1}=\mathrm{R}_{2}=\mathrm{H}$ verbascoside

$R_{1}=M e ; R_{2}=H$ leucosceptoside $A$

$\mathrm{R}_{1}=\mathrm{Me} ; \mathrm{R}_{2}=\mathrm{Me}$ martynoside

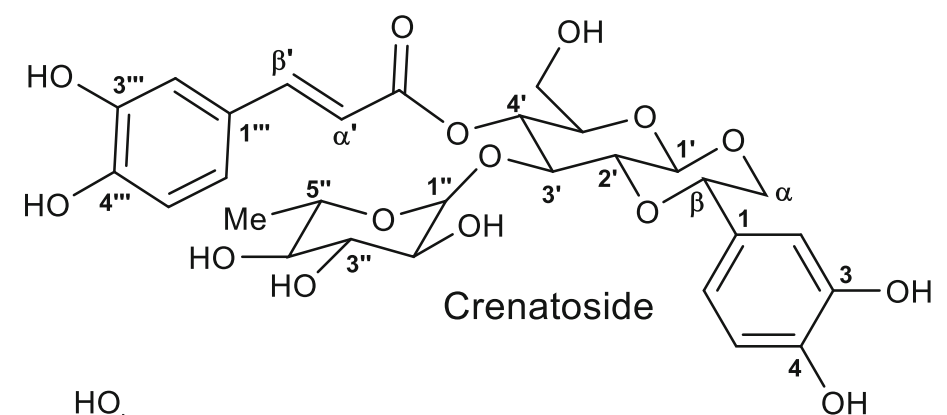

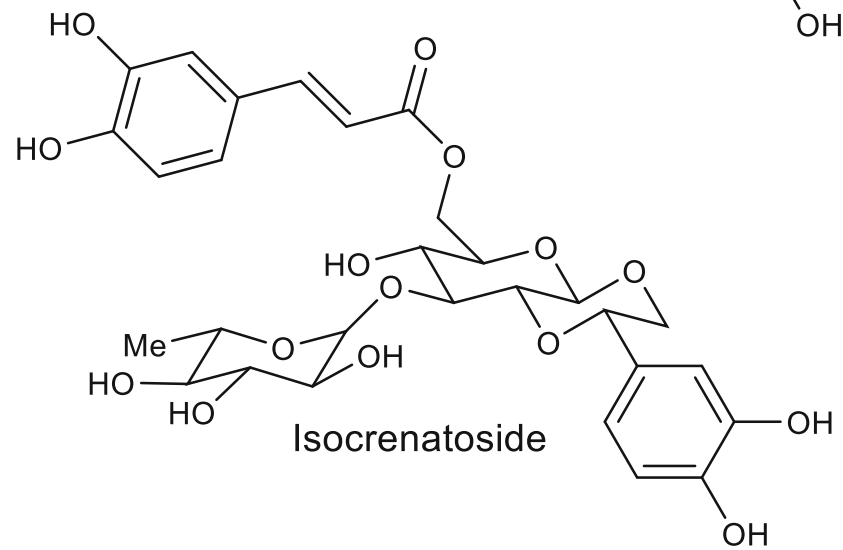

Fig. 4 Chemical structures of phenylethanoids glycoside from the leaves and trunk of Tecoma species 
crenatoside obtained from ethyl acetate fraction is shown in Fig. 4.

\section{Antiviral assay of Tecoma species extract and constituent} The ethanolic extracts of species from genus Tecoma, $T$. stans var. stans, T. stans var. angustata, T. castaneifolia and T. garrocha, were evaluated for in vitro antiviral against the Zika virus in Vero cell line, in non-cytotoxic concentrations. In the cytotoxic concentrations $\left(\mathrm{CC}_{50}\right)$ of the extracts, the fractions from trunk ethanol extract of $T$. stans and crenatoside were previously determined at concentrations ranging from 200 to $0.125 \mu \mathrm{g} / \mathrm{mL}$. The trunk extracts were more cytotoxic than the respective leaves extracts. The extracts from the leaves and the fractions from $T$. stans were not cytotoxic in the highest concentration tested $(200.0 \mu \mathrm{g} / \mathrm{mL})$, while the $\mathrm{CC}_{50}$ of the trunk extracts ranged from 159.0 to $0.1954 \mu \mathrm{g} / \mathrm{mL}$, in Vero cell line. Similarly, the $\mathrm{CC}_{50}$ determined in MRC-5 cells showed that the trunks are more cytotoxic than the leaves of the respective Tecoma species.

The in vitro anti-Zika virus activity by MTT assay was determined as the mean effective concentration $\left(\mathrm{EC}_{50}\right)$, and the trunk extract of $T$. castaneifolia presented $\mathrm{EC}_{50}$ of $66.78 \mu \mathrm{g} / \mathrm{mL}$, while the leaf extract presented $\mathrm{EC}_{50}$ of $61.25 \mu \mathrm{g} / \mathrm{mL}$, with selectivity indexes of 1.53 and 3.27, respectively. The $T$. garrocha specie showed to be less active. This trunk extract gave $\mathrm{EC}_{50}$ of $131.0 \mu \mathrm{g} / \mathrm{mL}$ and the leaves extract presented $\mathrm{EC}_{50}$ of $149.90 \mu \mathrm{g} / \mathrm{mL}$ with SI less than 1.5. The trunk extract of T. stans var. angustata and T. stans var. stans were not active against the Zika virus. Nevertheless, the analysis of the leaves extracts from these two specimens indicated activity with $\mathrm{EC}_{50}$ below $100.0 \mu \mathrm{g} / \mathrm{mL}$. Thus, the T. stans var. angustata extract showed a better antiviral activity with $\mathrm{EC}_{50}$ of $53.62 \mu \mathrm{g} / \mathrm{mL}$ followed by $T$. stans var. stans extract with a moderate activity of $\mathrm{EC}_{50}$ of $98.39 \mu \mathrm{g} / \mathrm{mL}$ and selectivity indexes greater than 3.73 and 2.03, respectively.

The ethyl acetate (TSSEF) and aqueous (TSSAF) fractions of $T$. stans var. stans trunk ethanolic extract was active against the Zika virus with $\mathrm{EC}_{50}$ values of 149.90 and $78.98 \mu \mathrm{g} / \mathrm{mL}$, and selectivity indexes of 1.33 and 2.53 , respectively.

The crenatoside, isolated from the ethyl acetate fraction of the T. stans var. stans trunk ethanolic extract presented better activity than the origin extract and the ethyl acetate fraction with $\mathrm{EC}_{50}$ of $34.78 \mu \mathrm{M}$ and SI of 4.25. In this assay, ribavirin was used as positive control and it presented an $\mathrm{EC}_{50}$ of $386.85 \mu \mathrm{M}$ and SI of 3.92.

The results including effective concentrations $\left(\mathrm{EC}_{50}\right)$ from each extract, isolated compound and positive control are described in Table 3, as well as the results of cytotoxicity concentrations $\left(\mathrm{CC}_{50}\right)$ for Vero and MRC-5 cell lines.
The selectivity index (SI) can be a parameter selection to predict promising drugs, it reflects the potency and possible selectivity for future drug development. The SI for active ethanolic extracts ranged from 1.21 to 3.73 . The ribavirin used as a positive control showed a SI of 3.92, while the isolated compound crenatoside showed better SI of 4.25 revealing its potent in vitro anti-Zika virus activity.

In order to confirm the anti-Zika virus activity observed in the MTT assay, extracts and isolated crenatoside compound were subjected to an in vitro cytopathic effect inhibition assay. In these experiments, challenges were performed where the extracts and compounds were tested in fixed concentrations. After $24 \mathrm{~h}$, the presence or absence of viral cytopathic effect was observed under an optical microscope (Figs. 5, 6 and 7). In Figs. 5, 6 and 7, it was possible to observe that every extract and isolated compound inhibit the viral cytopathic effect. They showed antiviral activity with monolayer cell protection greater than $80 \%$ for all tested substances when compared to the viral control.

\section{Discussion}

The phytochemical investigation of ethanolic extracts in the Tecoma species showed the presence of phenolic compounds such as lignans, phenylethanoids glycosides and flavonoids. The trunks ethanolic extracts from all studied species were more cytotoxic when compared to the extracts of the respective leaves, while the highlights were the trunk extracts in two varieties of $T$. stans. The analyzes by UPLC-DAD-MS showed the presence of lignans in these two extracts. In addition, it has been described in the literature that, in general, the antiviral effects of lignans are not strong [23]. The presence of lignans in the extracts of the two varieties of $T$. stans studied could justify the greater cytotoxicity observed in these extracts when compared to the extracts of the other Tecoma species tested and the non-activity against the Zika virus.

Phenylethanoid glycosides are present in all extracts of the Tecoma species from this present study. Literature reports only low to moderate cytotoxicity for this class of compounds [24]. Leaves extracts of the Tecoma species presented only low cytotoxicity despite high levels of phenylethanoids glycosides. The anti-Zika virus activity was observed for all Tecoma leaves extracts and almost all trunk extracts, except for the $T$. stans varieties.

In the literature, there are reports of the antiviral activity of the phenylethanoids glycosides verbascoside and isoverbascoside that were characterized in all Tecoma species. The verbascoside and isoverbascoside showed a potent in vitro activity against Human Immunodeficiency virus type 1 (HIV-1) with $\mathrm{EC}_{50}$ of 7.8 and $13.7 \mu \mathrm{M}$, respectively [25]. Furthermore, verbascoside was evaluated 
Table 3 Antiviral $\left(\mathrm{EC}_{50}\right)$ and cytotoxic $\left(\mathrm{CC}_{50}\right)$ activity of Tecoma species extract and constituents

\begin{tabular}{|c|c|c|c|c|c|}
\hline \multirow[t]{2}{*}{ Extract/compound } & & \multirow{2}{*}{$\begin{array}{l}\text { MRC-5 } \\
C_{50} \mu \mathrm{g} / \mathrm{mL}(\mu \mathrm{M})^{\mathrm{a}}\end{array}$} & \multirow{2}{*}{$\begin{array}{l}\text { Vero } \\
\mathrm{CC}_{50} \mu \mathrm{g} / \mathrm{mL}(\mu \mathrm{M})^{\mathrm{a}}\end{array}$} & ZIKV & \multirow[t]{2}{*}{${ }^{\mathrm{c}} \mathrm{SI}$} \\
\hline & & & & $E C_{50} \mu \mathrm{g} / \mathrm{mL}(\mu \mathrm{M})^{b}$ & \\
\hline \multirow[t]{2}{*}{ Tecoma castaneifolia } & Trunk & $131.30 \pm 1.39$ & $102.20 \pm 2.15$ & $66.78 \pm 3.01$ & 1.53 \\
\hline & Leaves & $>200.00$ & $>200.00$ & $61.25 \pm 2.65$ & $>3.27$ \\
\hline \multirow[t]{2}{*}{ Tecoma garrocha } & Trunk & $>200.00$ & $159.00 \pm 1.38$ & $131.00 \pm 1.56$ & 1.21 \\
\hline & Leaves & $>200.00$ & $>200.00$ & $149.90 \pm 1.52$ & $>1.33$ \\
\hline \multirow[t]{2}{*}{ Tecoma stans var. angustata } & Trunk & $80.25 \pm 1.18$ & $0.4750 \pm 1.28$ & $>200.00$ & - \\
\hline & Leaves & $144.10 \pm 1.33$ & $>200.00$ & $53.62 \pm 3.25$ & $>3.73$ \\
\hline \multirow[t]{2}{*}{ Tecoma stans var. stans } & Trunk & $0.4258 \pm 1.30$ & $0.1934 \pm 1.22$ & $>200.00$ & - \\
\hline & Leaves & $>200.00$ & $>200.00$ & $98.39 \pm 1.40$ & $>2.03$ \\
\hline TSSDF & & $N T^{d}$ & $86.94 \pm 2.08$ & $>200.00$ & - \\
\hline TSSEF & & $N T^{d}$ & $>200.00$ & $149.90 \pm 3.03$ & 1.33 \\
\hline TSSAF & & $N T^{d}$ & $>200.00$ & $78.98 \pm 1.54$ & 2.53 \\
\hline Crenatoside & & $\begin{array}{l}>100.00 \\
(>160.74)\end{array}$ & $\begin{array}{l}92.06 \pm 1.47 \\
(147.98 \pm 1.47)\end{array}$ & $\begin{array}{l}21.64 \pm 1.57 \\
(34.78 \pm 1.57)\end{array}$ & 4.25 \\
\hline Ribavirin & & $\begin{array}{l}52.66 \pm 1.18 \\
(215.65 \pm 1.18)\end{array}$ & $\begin{array}{l}370.40 \pm 1.20 \\
(1516.75 \pm 1.20)\end{array}$ & $\begin{array}{l}94.47 \pm 2.70 \\
(386.85 \pm 2.70)\end{array}$ & 3.92 \\
\hline
\end{tabular}

a $50 \%$ cytotoxic concentration

b $50 \%$ effective concentration of viral replication

c $\mathrm{SI}$ (Selectivity index): ratio between extract/compound $\mathrm{CC}_{50}$ and $\mathrm{EC}_{50}$

${ }^{d}$ NT: Not tested

against Herpes Simplex virus exhibiting $\mathrm{EC}_{50}$ values of $58 \mu \mathrm{g} / \mathrm{mL}(92.95 \mu \mathrm{M})$ to HSV -1 and $8.9 \mu \mathrm{g} / \mathrm{mL}$ to HSV-2 $(14.26 \mu \mathrm{M})$ [26]. Therefore, the data suggest that the antiviral activity against the Zika virus may be related to the presence of the characterized phenylethanoids glycosides in Tecoma species.

Flavonoids such as rutin, apigenin and methoxyluteolin were detected in leaf extracts of $T$. garrocha and $T$. stans var. angustata. The protective effect during plant tissue injury is widespread by antioxidant activity of these compounds [27]. Rutin was identified in leaves extract from $T$. garrocha among other flavonoids. It has been distinguished by various pharmacological activities [28]. According to studies by Afanas'Ev et al., rutin and quercetin, showed antioxidant activity. Therapeutic action of these two flavonoids in pathologies involving free radicals are non-toxic, especially in rutin [29]. There are no studies in the literature demonstrating the antiviral activity of rutin. However, there are reports that associate the antioxidant activity of substances with antiviral activity $[20,30]$. Thus, the presence of rutin in the species $T$. garrocha may be responsible for the contribution to the activity of the anti-Zika virus observed in this species.

In addition, the rich fraction of Cynodon dactylon containing luteolin and apigenin as the major phytochemicals exhibited a potent viral inhibitory activity (about 98\%) at a concentration of $50 \mu \mathrm{g} / \mathrm{mL}$ against the Chikungunya virus [31]. From this, it is possible to suggest that the presence of apigenin and methoxyluteolin in the species $T$. stans var. angustata may contribute to the antiviral activity against the Zika virus observed.

The biofractionation of $T$. stans var. stans trunk extract led to the isolation of crenatoside that was obtained from the ethyl acetate fraction (TSSEF). It has been identified employing usual spectrometric and spectroscopy techniques followed by comparison with the literature $[21,22]$, the ${ }^{13} \mathrm{C}$ and ${ }^{1} \mathrm{H}$ NMR and DEPT spectra data and monography are shown in the Supplementary Material (Fig. 9S to 15S).

Crenatoside is a phenylethanoid glycoside containing glycosidic linkage, as well as an ether linkage between a glucose moiety and a 3,4-dihydroxyphenylethanol moiety [32]. Phenylethanoid glycoside moiety was considered a chemical marker of the Orobanche species [33], usually called orobanchoside and oraposide. According to Nishibe et al., [34], these two named structures are the same molecule. In the Bignoniaceae family, its occurrence was reported in Incarvillea compacta [35]. This was the first one reported of its isolation in Tecoma species.

The zika fever emerged as a threat in the western hemisphere in 2015 and the peak of the Zika virus infection occurred in 2016, and over the following years the cases decreased substantially in the Americas region [36, 37]. In mid-2019, the WHO data revealed that 87 countries and territories worldwide recorded autochthonous Zika virus transmission by mosquito-borne [1]. However, there is a probable risk of Zika infection to spread to more countries, as well as chances for the potential re-emergence of 

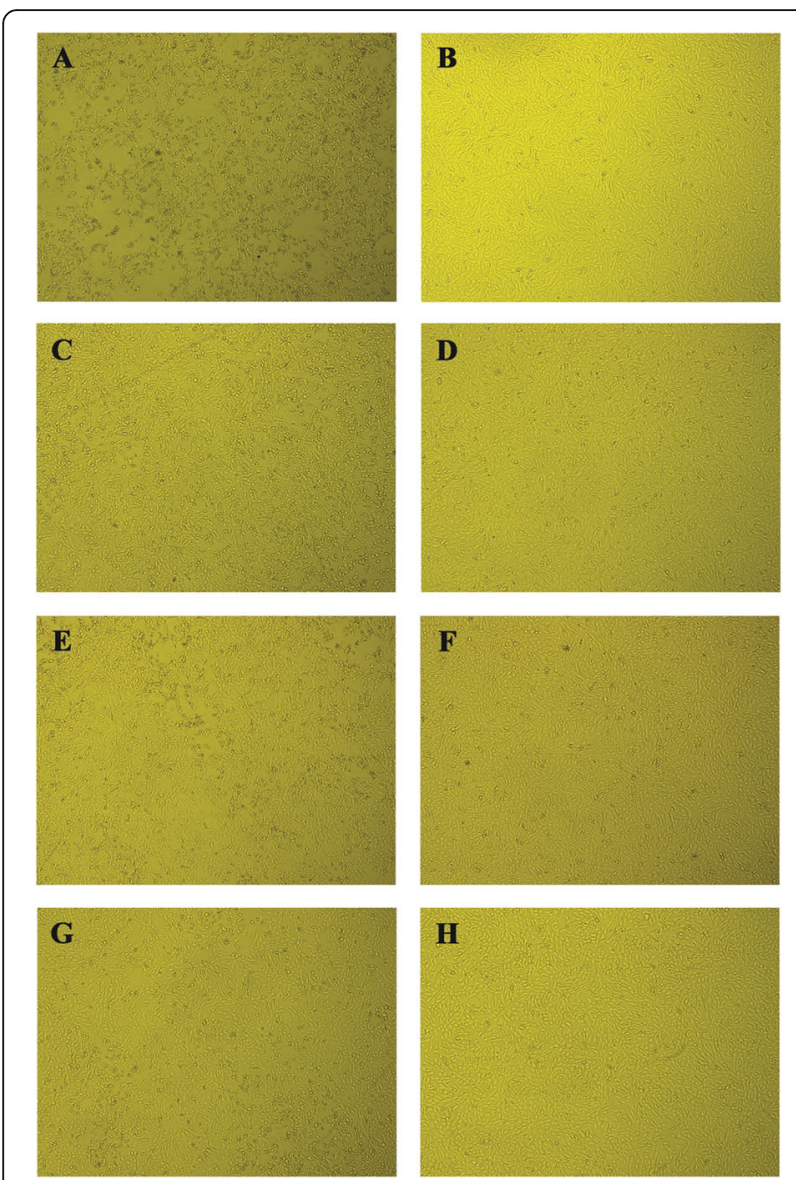

Fig. 5 Antiviral effect against Zika virus in Vero cells treated with Tecoma species leaves extracts. Vero cells were infected with ZIKV, treated with Tecoma leaves ethanolic extracts and photographed after $24 \mathrm{~h}$ of infection. a Infected cells, b Uninfected and untreated cells, c Cells infected and treated with T. castaneifolia leaf $(50 \mathrm{\mu g} /$ $\mathrm{mL}), \mathbf{d}$ Cells uninfected and treated with T. castaneifolia leaf $(50 \mathrm{\mu g} /$ $\mathrm{mL})$, e Cells infected and treated with T. garrocha leaf $(200 \mu \mathrm{g} / \mathrm{mL}), \mathbf{f}$. Cells uninfected and treated with T. garrocha leaf $(200 \mu \mathrm{g} / \mathrm{mL}), \mathbf{g}$ Cells infected and treated with T. stans var. angustata leaf $(50 \mathrm{\mu g} /$ $\mathrm{mL}$ ), $\mathbf{h}$ Cells uninfected and treated with $T$. stans var. angustata leaf $(50 \mu \mathrm{g} / \mathrm{mL})$, Magnification, $100 \mathrm{x}$

the virus in all places where ZIKV transmission has been reported previously [37].

Therefore, from the aforementioned, the Zika fever remains a global health threat and it has the potential to re-emerge as an epidemic, furthermore there are no effective vaccine and/or antiviral drugs to prevent or treat Zika infection [37]. In this context, this study proposed to evaluate the anti-Zika virus activity of ethanol extracts from Tecoma species and promising isolated compound.

The evaluation of antiviral activity against Zika virus by Tecoma species shows that leaves extracts were more active than trunk extracts (Table 3). Cos et al. [18] and Ocazionez et al. [19] consider that antiviral activity is selective and relevant with the standard criteria adopted below: $\mathrm{CC}_{50} \geq 100.0 \mu \mathrm{g} / \mathrm{mL}$, the $\mathrm{EC}_{50} \leq 50.0 \mu \mathrm{g} / \mathrm{mL}$ and
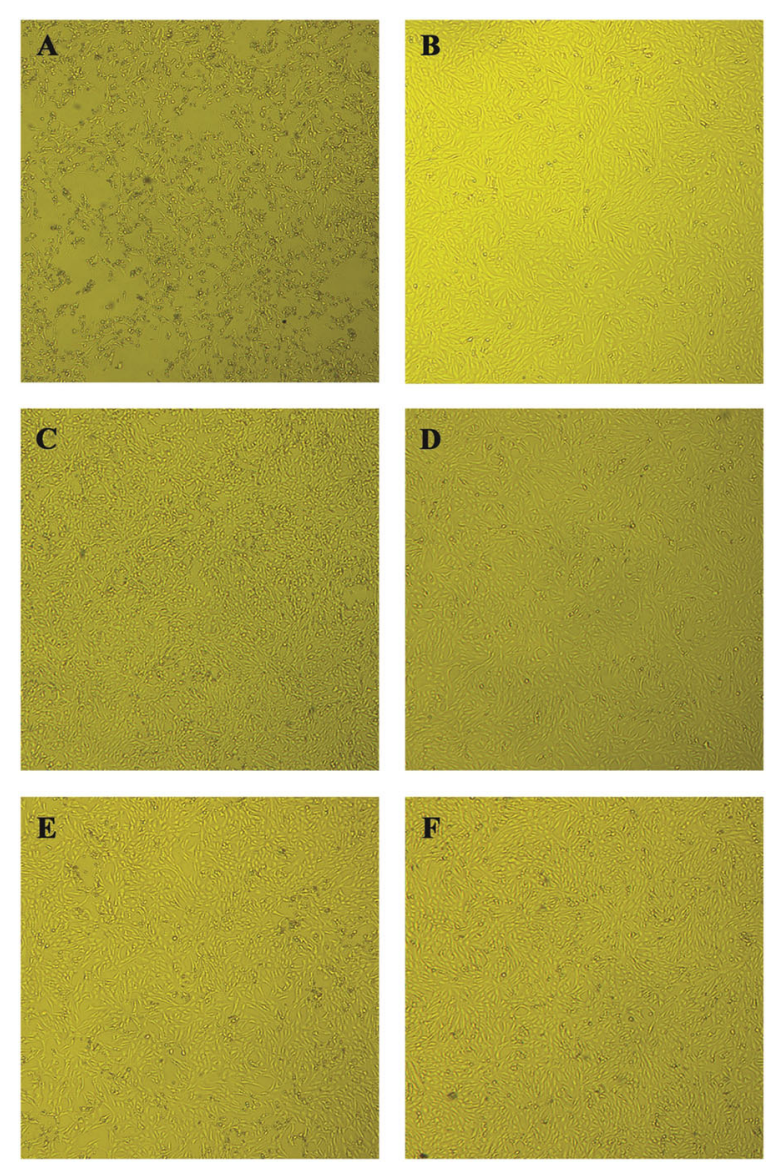

Fig. 6 Antiviral effect against Zika virus in Vero cells treated with Tecoma species trunk extracts. Vero cells were infected with ZIKV, treated with Tecoma trunk ethanolic extracts and photographed after $24 \mathrm{~h}$ of infection. a Infected cells, b Uninfected and untreated cells, c Cells infected and treated with T. castaneifolia trunk $(50 \mu \mathrm{g} /$ $\mathrm{mL}$ ), d Cells uninfected and treated with T. castaneifolia trunk $(50 \mu \mathrm{g} / \mathrm{mL})$, e Cells infected and treated with T. garrocha trunk $(200 \mu \mathrm{g} / \mathrm{mL}), \mathbf{f}$ Cells uninfected and treated with T. garrocha trunk $(200 \mu \mathrm{g} / \mathrm{mL})$. Magnification, 100x

the selectivity index $\geq 2.0[18,19]$. Therefore, the leaves extract of T. castaneifolia, T. stans var. angustata and T. stans var. stans presented a better selectivity index (SI > 2.0). More in depth studies with these species might be really promising in order to further investigate antivirus activity.

This paper describes for the first time, the anti-Zika virus activity of these Tecoma species. However, in relation to the Tecomeae tribe (Bignoniaceae), there are few reports in the literature about the antiviral activity of the species in the Tabebuia and Tecoma genera. In the ElMekkawy et al. [38] study, the methanol extract from the aerial parts of Tabebuia pentaphylla was active against HIV-1 at a concentration of $100.0 \mu \mathrm{g} / \mathrm{mL}$, and presented a weak inhibition $(<50.0 \%)$ of the activity of the enzyme reverse transcriptase ribonuclease $\mathrm{H}$. While 

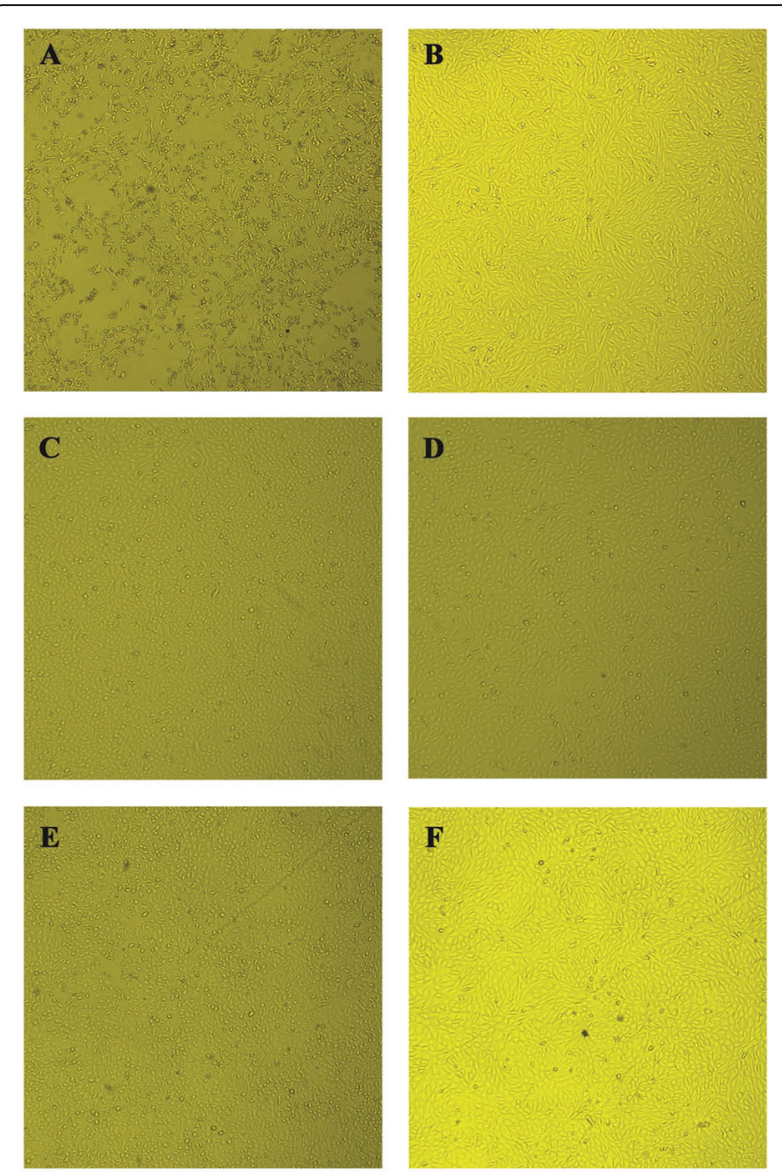

Fig. 7 Antiviral effect against Zika virus in Vero cells treated with Crenatoside and the positive control Ribavirine. Vero cells were infected with ZIKV, treated with the isolated compound, crenatoside, and the positive control, ribavirine, then photographed after $24 \mathrm{~h}$ of infection. a Infected cells, b Uninfected and untreated cells, c Cells infected and treated with crenatoside $(25 \mu \mathrm{g} / \mathrm{mL})$, d Cells uninfected and treated with crenatoside $(25 \mu \mathrm{g} / \mathrm{mL})$, e Cells infected and treated with ribavirine $(100 \mu \mathrm{g} / \mathrm{mL}), \mathbf{f}$ Cells uninfected and treated with ribavirine $(100 \mu \mathrm{g} / \mathrm{mL})$. Magnification, 100x

the methanol extracts of Tabebuia pentaphylla and Tecoma grandis exhibited moderately inhibition (65.90 and $57.60 \%$, respectively) of the HIV-1 protease.

Other Bignoniaceae family species with antivirus activity have been previously reported including in vitro antiDengue virus type 2 activity, a flavivirus that has a genetic and serological relationship with the Zika virus, of Fridericia sp. [5; 8], Distictella elongate [39], Xylofragma myrianthum [40]. Markhamia lutea extract presented in vitro activity against Respiratory syncytial virus [6].

According to this study, the phenylethanoid crenatoside antiviral activity shows that it is a promising substance with in vitro anti-Zika virus activity, that is, it presents selective and relevant activity when compared to standard criteria [18, 19]. Although its cytotoxicity $\left(\mathrm{CC}_{50}\right)$ is slightly less than $100 \mu \mathrm{g} / \mathrm{mL}$ in Vero cell line, the crenatoside was not cytotoxic in MRC-5 cells at the highest concentration tested, hence according to the recommendations described by Cos et al. [18]. Thus, crenatoside is a promising substance with antiviral activity.

Comparing the crenatoside antiviral activity with the ethanolic extracts of Tecoma species, it was at least 2.5 times more active than the crude extracts, in relation to the origin ethyl acetate fraction, and crenatoside was 4.3 times more active. Furthermore, when compared with the positive control, ribavirin, it was 4.4 times more active against ZIKV. Until today, there is no specific treatment for the Zika fever, therefore, ribavirin was chosen as a positive control because it is an antiviral approved drug used to treat hepatitis C. Like the Zika virus, the Hepatitis $C$ virus is a member of the Flaviviridae family, and in vitro and in vivo studies have shown the ribavirin potential to inhibit the Zika virus.

There were some crenatoside biological activities previously reported such as: antioxidant activity, platelet aggregation, Respiratory syncytial inhibition; antihypertensive; analgesic [41], inhibition of aldose reductase; antitremor L-DOPA [42] among others. The only crenatoside antiviral reported activity was against the Influenza virus type A [43], which presented an inhibitory effect of $89.81 \mu \mathrm{g} / \mathrm{mL}(144.36 \mu \mathrm{M})$.

The crenatoside is four times more active against the Zika virus than the Influenza virus type A, although the Zika virus and the Influenza virus are viruses enveloped with RNA genetic material $[44,45]$. Morphology disparities can explain the different results for these viruses, for example, ZIKV is a flavivirus that contains a singlestranded positive-sense [44], while the Influenza virus presents a single-stranded negative-sense and belongs to the Ortomyxoviridae family [45].

The results obtained in the in vitro cytopathic effect inhibition assay demonstrated that the cell monolayer infected by the Zika virus allows viral multiplication inside the cells leading to the cell monolayer destruction that was observed in the images (item A - Figs. 5, 6 and 7). These can be seen by the destruction and morphological alterations of the cells such as rounding of cells, formation of lumps and changes in cell refringence, especially when compared to the uninfected and untreated cell monolayer (item B - Figs. 5, 6 and 7).

While treating the ZIKV-infected cell monolayer with extracts and / or the substance alone, it is possible to protect the cells from a virus infection, and thus prevent cell death once the cells remain attached (such as a monolayer) and no morphocellular deformities are observed. Therefore, they indicate that the treatment performed after infection is effective in inhibiting the virus multiplication cycle, confirming the antiviral activity observed in the MTT colorimetric assay. 
This shows crenatoside is an interesting promisor drug with selective and relevant in vitro anti-Zika virus activity. Moreover, the complex structure of the crenatoside allows for many chemical modifications. Thus, future studies of this molecule might provide relevant data to produce antivirus molecules.

\section{Conclusions}

Our results reveal that Tecoma species showed in vitro antiviral activity against the Zika virus and crenatoside. The first time it was isolated from the Tecoma stans var. stans, it exhibited a potent and relevant anti-Zika virus, being more active than ribavirin (positive control). This data suggests that crenatoside is a promisor compound against the Zika virus and future studies of this molecule might provide relevant data to produce antivirus molecules. Furthermore, the bioactivity of crenatoside should be investigated against other viruses.

The phytochemical investigation of Tecoma species allowed the detection of phenylethanoids glycosides such as verbascoside, isoverbascoside and crenatoside in the trunk and leaves, furthermore, some lignans and flavonoids were detected. The biomonitored studies with Tecoma species are being carried out by our research group to isolate other bioactive compounds with promising antiviral activity, such as crenatoside.

\section{Supplementary information}

Supplementary information accompanies this paper at https://doi.org/10. 1186/s12906-020-03040-0.

Additional file 1: Fig. 1S. Mass spectrum in negative mode of Tecoma castaneifolia trunk. Figure 2S. Mass spectrum in negative mode of Tecoma castaneifolia leaves. Figure $\mathbf{3 S}$. Mass spectrum in negative mode of Tecoma garrocha trunk. Figure 4S. Mass spectrum in negative mode of Tecoma garrocha leaves. Figure 5S. Mass spectrum in negative mode of Tecoma stans var. angustata trunk. Figure $\mathbf{6 S}$. Mass spectrum in negative mode of Tecoma stans var. angustata leaves. Figure 7S. Mass spectrum in negative mode of Tecoma stans var. stans trunk. Figure $\mathbf{8 S}$. Mass spectrum in negative mode of Tecoma stans var. stans leaves. Figure 9S. $1 \mathrm{H}-\mathrm{NMR}$ spectrum of crenatoside $(400 \mathrm{MHz}$, DMSO-d6 e MeOD. Figure 10S. 1H-NMR spectrum expansion 7.7 to $6.3 \mathrm{ppm}$ of crenatoside $(400 \mathrm{MHz}$, DMSO-d6 e MeOD, $\delta)$. Figure 11S. $1 \mathrm{H}-\mathrm{NMR}$ spectrum expansion 5.2 to 4.5 ppm of crenatoside $(400 \mathrm{MHz}$, DMSO-d6 e MeOD, $\delta)$. Figure 12S. 1H-NMR spectrum expansion 4.2 to $3.2 \mathrm{ppm}$ of crenatoside (400 MHz, DMSO-d6 e MeOD, $\delta$ ). Figure 13S. 1H-NMR spectrum expansion 1.3 to 0 ppm of crenatoside ( $400 \mathrm{MHz}$, DMSO-d6 e MeOD, $\delta$ ). Figure 14S. 13C-NMR spectrum of crenatoside (100 MHz, DMSO-d6 e MeOD, 8). Figure 15S. 13C-NMR spectrum of crenatoside (DEPT-135, $100 \mathrm{MHz}$, DMSO-d6 e MeOD, $)$.

\section{Abbreviations}

ATCC: American Type Culture Collection; $\mathrm{CC}_{50}$ : 50\% of Citotoxicity Concentration; $\mathrm{CH}_{2} \mathrm{Cl}_{2}$ : Dichloromethane; CPE: cytopathic effect; DAD: Diode Array Detector; DMEM: Dulbecco Modified Eagle Medium; DMSO: dimethyl sulfoxide; DMSO-d6: Deuterated dimethyl sulfoxide; ESI: Electrospray Ionization; EtOAc: ethyl acetate; $\mathrm{EC}_{50}$ : $50 \%$ of Effective Concentration; FBS: Fetal Bovine Serum; HIV: Human Immunodeficiency virus; HSV: Herpes simplex virus; LD: Liquid Chromatography; MeOD: Deuterated methanol; MeOH: Methanol; MOI: Multiplicity Of Infecction; MS: Mass Spectrometry; MTT: 3-(4,5-Diamethylthiazol-2-yl)-2,5-Diphenyltetrazolium Bromide;
NMR: Nuclear Magnetic Resonance; NT: Not tested; SI: selectivity index; $\mathrm{TCID}_{50}$ : 50\% tissue culture infective dose; TLC: Thin Layer Chromatography; TSSAF: Tecoma stans var. stans trunk aqueous fraction; TSSDF: Tecoma stans var. stans trunk dichloromethane fraction; TSSEF: Tecoma stans var. stans trunk ethyl acetate fraction; UPLC: Ultra Performance Liquid Chromatography; UV: Ultraviolet; WHO: World Health Organization; ZIKV: Zika virus

\section{Acknowledgements}

Thanks to Dr. J.R. Stehman, Botanical Department, Institute of Biological Sciences, at UFMG, in Belo Horizonte, Brazil, for collection and taxonomical determination of Tecoma species. We also would like to thank the Phytochemistry Laboratory from the School of Pharmacy - UFMG on behalf of Dr. A.B. Oliveira and F.C. Braga for the equipment availability used in the chromatographic analysis.

\section{Authors' contributions}

ACCR conducted the entire phytochemical study and the biological assays. BMS contributed to the biological assays. HMMM contributed to the antiviral assays. GRP contributed with the NMR analyzes and orthographic corrections of the main text. GCB contributed to the phytochemical study including the UPCL-DAD-MS analyzes in the biological assays. All authors read and approved the final manuscript.

\section{Funding}

This work was supported by funds from FAPEMIG - Fundação de Amparo à Pesquisa do Estado de Minas Gerais (Brazil), process number CDS- APQ00270-13 and process number CDS - APQ-01529-15 providing research resources for acquisition of materials and equipment. CNPq - Conselho Nacional de Desenvolvimento Científico e Tecnológico (Brazil) - INCT Dengue (DenguelMH) PROCESS N.: 465425/2014-3 which provided funds for the acquisition of LCMS equipment. PROPP-UFOP - Pró-Reitoria de Pesquisa e Pós-Graduação da UFOP, process number 23109.003267/2017-01 providing scholarships, building facilities, as well as the research resources including the acquisition of materials and reagents.

\section{Availability of data and materials}

Not applicable;

Ethics approval and consent to participate

Not applicable;

Consent for publication

Not applicable;

\section{Competing interests}

The authors declare that they have no competing interests;

\section{Author details}

${ }^{1}$ Pharmacy Department, School of Pharmacy, Federal University of Ouro Preto, Campus Morro do Cruzeiro, Ouro Preto, Minas Gerais 35400-000, Brazil. ${ }^{2}$ Department of Biological Sciences, ICEB, Federal University of Ouro Preto, Campus Morro do Cruzeiro, Ouro Preto, Minas Gerais, Brazil. ${ }^{3}$ Department of Physics and Chemistry, Institute of Exact Sciences and IT (ICEI), Catholic Pontifical University of Minas Gerais, PUC Minas, Belo Horizonte, Minas Gerais, Brazil.

Received: 5 April 2019 Accepted: 31 July 2020

Published online: 07 August 2020

\section{References}

1. World Health Organization. https://www.who.int/news-room/fact-sheets/ detail/zika-virus. Accessed: 2019 Mar 01

2. Brasil. Ministério da Saúde - Boletim epidemiológico 47. 2018. http:// portalarquivos2.saude.gov.br/images/pdf/2018/novembro/12/2018-034.pdf. Accessed: 2019 Mar 01.

3. Chattopadhyay D, Naik TN. Antivirals of ethnomedicinal origin: structureactivity relationship and scope. Mini-Reviews Med Chem. 2007;7(3):275-301.

4. Oliveira AB, Raslan DS, Miraglia MCM, Mesquita AAL, Zani CL, Ferreira DT, et al. Chemical structures and biological activities of naphthoquinones from Brazilian Bignoniaceae. Quim Nova. 1990;13:302-7. 
5. Brandão GC, Kroon EG, Souza Filho JD, Oliveira AB. Antiviral activity of Fridericia formosa (bureau) LG Lohmann (Bignoniaceae) extracts and constituents. J Trop Med. 2017. https://doi.org/10.1155/2017/6106959.

6. Kernan MR, Amarquaye A, Chen JL, Chan J, Sesin DF, Parkinson N, et al. Antiviral phenylpropanoid glycosides from the medicinal plant Markhamia lutea. J Nat Prod. 1998:61:564-70.

7. Lagrota MHC, Wigg MD, Pereira LOB, Fonseca MEF, Pereira NA, Guimaraes JC. Antiviral activity of lapachol. Rev Microbiol. 1983;14:21-6.

8. Brandão GC, Kroon EG, Souza DER, Filho JDS, Oliveira AB. Chemistry and antiviral activity of Arrabidaea pulchra (Bignoniaceae). Molecules. 2013;18: 9919-32. https://doi.org/10.3390/molecules18089919.

9. Brandão GC, Kroon EG, Dos Santos JR, Stehmann JR, Lombardi JA, Oliveira $A B$. Antiviral activity of Bignoniaceae species occurring in the state of Minas Gerais (Brazil): part 1. Lett Appl Microbiol. 2010;51(4):469-76. https://doi.org/ 10.1111/j.1472-765X.2010.02924.X

10. Brandão GC, Kroon EG, Dos Santos JR, Stehmann JR, Lombardi JA, Oliveira AB. Antiviral activities of plants occurring in the state of Minas Gerais, Brazil. Part 2. Screening bignoniaceae species. Brazilian J of Pharmacog. 2010;20(5): 742-50. https://doi.org/10.1590/S0102-695X2010005000035.

11. Ficher E, Theisen I, Lohmann LG. In: Kubitzki K, Bayer C, editors. The families and genera of vascular plants. Berlim: Heidelberg Springer-Verlag; 2004. p. 9-38.

12. Gentry AH. Bignoniaceae: part II (tribe Tecomeae). In: Flora Neotropica Organization, editor. Flora Neotropica Monograph. 1st ed. New York: The New York Botanical Garden; 1992. p. 273-297.

13. Verma S. Phytochemical and pharmacological review study on Tecoma stans Linn. J Med Plants Studies. 2016:4:162-4.

14. Rodriguez DJ, Chulia J, Simões CMO, Amoros M, Mariotte AM, Girre L. Search for in vitro antiviral activity of a new isoflavonic glycoside from Ulex europaeus. Planta Med. 1990;56:59-62.

15. Twentyman PR, Luscombe M. A study of some variables in a tetrazolium dye (MTT) based assay for cell growth and chemosensitivity. British J Cancer. 1987;56:279.

16. Betancur-Galvis LA, Morales GE, Forero JE, Roldan J. Cytotoxic and antiviral activities of colombian medicinal plant extracts of the Euphorbia genus. Mem Inst Oswaldo Cruz. 2002:97:541-6.

17. Kamiyama N, Soma R, Hidano S, Watanabe K, Umekita H, Fukuda C, et al. Ribavirin inhibits Zika virus (ZIKV) replication in vitro and suppresses viremia in ZIKV-infected STAT1-deficient mice. Antivir Res. 2017;146:1-11. https://doi. org/10.1016/j.antiviral.2017.08.007.

18. Cos P, Vlietinck AJ, Vanden BD, Maes L. Anti-infective potential of natural products: How to develop a stronger in vitro "proof-of-concept". J Ethnopharmacol. 2006;106(3):290-302.

19. Ocazionez RE, Meneses R, Torres FÁ, Stashenko E. Virucidal activity of Colombian Lippia essential oils on dengue virus replication in vitro. Mem Inst Oswaldo Cruz. 2010;105(3):304-9.

20. Camini FC, da Silva TF, da Silva Caetano CC, Almeida LT, Ferraz AC, Vitoreti VMA, et al. Antiviral activity of silymarin against Mayaro virus and protective effect in virus-induced oxidative stress. Antivir Res. 2008:158:8-12.

21. Afifi MS, Lahloub MF, El-Khayaat SA, Anklin CG, Rüegger H, Sticher O. Crenatoside: a novel Phenylpropanoid glycoside from Orobanche crenata1. Planta Med. 1993;59:359-62.

22. Wu J, Huang J, Xiao Q, Zhang S, Xian Z, Li Q, et al. Complete assignments of ${ }^{1} \mathrm{H}$ and ${ }^{13} \mathrm{C}$ NMR data for 10 phenylethanoid glycosides. Mag Reson Chem. 2004;42:659-62.

23. Charlton JL. Antiviral activity of lignans. J Nat Prod. 1998;61(11):1447-51.

24. Xue Z, Yan R, Yang B. Phenylethanoid glycosides and phenolic glycosides from stem bark of Magnolia officinalis. Phytochem. 2016;127:50-62.

25. Kim HJ, Woo ER, Shin CG, Hwang DJ, Park H, Lee YS. HIV-1 integrase inhibitory phenylpropanoid glycosides from Clerodendron trichotomum. Arch Pharm Res. 2001;24(4):286-91.

26. Martins FO, Esteves PF, Mendes GS, Barbi NS, Menezes FS, Romanos MTV. Verbascoside isolated from Lepechinia speciosa has inhibitory activity against HSV-1 and HSV-2 in vitro. Nat Prod Commun. 2009;4(12):1693-6.

27. Tapas AR, Sakarkar DM, Kakde RB. Flavonoids as Nutraceuticals: a review. Tropical J Pharmaceutical Res. 2008;7:1089-99.

28. Marcarini JC, Tsuboy MSF, Luiz RC, Ribeiro LR, Hoffmann-Campo CB, Mantovani MS. Investigation of cytotoxic, apoptosis-inducing, genotoxic and protective effects of the flavonoid rutin in HTC hepatic cells. Exp Toxicol Pathol. 2011:63:459-65.
29. Afanas'ev IB, Dcrozhko Al, Brodskii AV, Kostyuk VA, Potapovitch Al. Chelating and free radical scavenging mechanisms of inhibitory action of rutin and quercetin in lipid peroxidation. Biochem Pharmacol. 1989;38:1763-9.

30. Panchal RG, Reid SP, Tran JP, Bergeron AA, Wells J, Kota KP, et al. Identification of an antioxidant small-molecule with broad-spectrum antiviral activity. Antivir Res. 2012;93(1):23-9. https://doi.org/10.1016/j. antiviral.2011.10.011.

31. Murali KS, Sivasubramanian S, Vincent S, Murugan SB, Giridaran B, Dinesh S, et al. Anti-chikungunya activity of luteolin and apigenin rich fraction from Cynodon dactylon. Asian Pac J Trop Med. 2015;8(5):352-8. https://doi.org/ 10.1016/S1995-7645(14)60343-6.

32. Lahloub MF, Rüegger H, El-Khayaat SA, Affifi MS, Sticher O. Crenatoside, a novel Phenylpropanoid glycoside from Orobanche crenata. Planta Med. 1989;55:612-3.

33. Dini I, lodice C, Ramundo E. Phenolic metabolites from Orobanche speciosa. Planta Med. 1995;61:389-90.

34. Nishibe S, Tamayama Y, Sasahara M, Andary C. A phenylethanoid glycoside from Plantago asiatica. Phytochemistry. 1995;38:741-3.

35. Shen $T$, Li X, Hu W, Zhang L, Xu X, Wu H, et al. Hepatoprotective effect of phenylethanoid glycosides from Incarvillea compacta against CCI4-induced cytotoxicity in HepG2 cells. J Korean Soc Appl Biological Chem. 2015;58: $617-25$.

36. Anderson JL. Zika virus: a review and clinical updates. Infect Dis Clin Pract. 2017;25(6):289-93.

37. Pielnaa P, Al-Saadawe M, Saro A, Dama MF, Zhou M, Huang Y, et al. Zika virus-spread, epidemiology, genome, transmission cycle, clinical manifestation, associated challenges, vaccine and antiviral drug development. Virology. 2020;543:34-42. https://doi.org/10.1016/j.virol.2020 01.015 .

38. El-mekkawy S, Abdel-sattar E, Hattori M, Takuya K, Toru O. Screening of Medicinal Plants in Egypt for Anti-Human Immunodeficiency Virus Type-1 (Hiv-1) Activity. 2009;4(1):2009.

39. Simões LR, Maciel GM, Brandão GC, Kroon EG, Castilho RO, Oliveira AB. Antiviral activity of Distictella elongata (Vahl) Urb. (Bignoniaceae), a potentially useful source of anti-dengue drugs from the state of Minas Gerais, Brazil. Letters Appl Microbiol. 2011;53:602-7.

40. Brandão GC, Kroon EG, Matos AW, Souza Filho JD, Oliveira AB. Bioguided isolation of an antiviral compound from Xylophragma myrianthum (Cham.) Sprague (Bignoniaceae Juss.). Rev Fitos. 2014;8(2):125-36.

41. Gálvez M, Martín-Cordero C, Ayuso MJ. Pharmacological activities of phenylpropanoids glycosides. Stud Nat Prod Chem. 2006;33:675-718.

42. Jiménez C, Riguera R. Phenylethanoid glycosides in plants: structure and biological activity. Nat Prod Rep. 1994;11(6):591-606.

43. Chen BL, Wang YJ, Guo H, Zeng GY. Design, synthesis, and biological evaluation of crenatoside analogues as novel influenza neuraminidase inhibitors. Eur J Med Chem. 2016;109:199-205. https://doi.org/10.1016/j. ejmech.2015.12.031.

44. Yun SI, Lee YM. Zika virus: An emerging flavivirus. J Microbiol. 2017;55(3): 204-19.

45. Noda T. Native morphology of influenza virions. Front Microbiol. 2012;2:269.

\section{Publisher's Note}

Springer Nature remains neutral with regard to jurisdictional claims in published maps and institutional affiliations.

Ready to submit your research? Choose BMC and benefit from:

- fast, convenient online submission

- thorough peer review by experienced researchers in your field

- rapid publication on acceptance

- support for research data, including large and complex data types

- gold Open Access which fosters wider collaboration and increased citations

- maximum visibility for your research: over $100 \mathrm{M}$ website views per year

At BMC, research is always in progress.

Learn more biomedcentral.com/submission 